\title{
Inhibitory Effects of Scopoletin in Collagen-induced Human Platelet Aggregation
}

\author{
Hyuk-Woo Kwon ${ }^{1}$, Jung-Hae Shin ${ }^{1}$, Chang-Eun Park ${ }^{2}$, Dong-Ha Lee ${ }^{2}$ \\ ${ }^{1}$ Department of Biomedical Laboratory Science, Far East University, Eumseong, Korea \\ ${ }^{2}$ Department of Biomedical Laboratory Science, Molecular Diagnostics Research Institute, Namseoul University, Cheonan, Korea
}

\section{콜라겐으로 유도한 사람 혈소판 응집에 미치는 Scopoletin의 억제 효과}

\author{
권혁우 ${ }^{1}$, 신정해 $^{1}$, 박창은 $^{2}$, 이동하 $^{2}$ \\ ${ }^{1}$ 극동대학교 임상병리학과, ${ }^{2}$ 남서울대학교 임상병리학과 · 분자진단연구소
}

\begin{abstract}
Platelet aggregation is essential for the formation of a hemostatic plug in the case of blood vessel damage. On the other hand, excessive platelet aggregation may cause cardiovascular disorders, such as thrombosis, atherosclerosis, and myocardial infarction. Scopoletin, which found in the root of plants in the genus Scopolia or Artemisia, has anti-coagulation and anti-malaria effects. This study examined the effects of scopoletin on human platelet aggregation induced by collagen. Scopoletin had anti-platelet effects via the down-regulation of thromboxane $A_{2}\left(T_{X A}\right)$ production and intracellular $\mathrm{Ca}^{2+}$ mobilization $\left(\left[\mathrm{Ca}^{2+}\right]_{\mathrm{i}}\right)$, which are aggregation-inducing molecules produced in activated platelets. On the other hand, scopoletin increased both the cyclic adenosine monophosphate (CAMP) and cyclic guanosine monophosphate (cGMP) levels, which are known as intracellular $\mathrm{Ca}^{2+}$-antagonists and aggregation-inhibiting molecules. In particular, scopoletin increased the potently cAMP level more than cGMP, which led to suppressed fibrinogen binding to $\alpha \mathrm{llb} / \beta_{3}$ in collagen-induced human platelet aggregation. In addition, scopoletin inhibited collagen-elevated adenosine triphosphate (ATP) release in a dose-dependent manner. The results suggest that aggregation amplification through granule secretion is inhibited by scopoletin. Therefore, scopoletin has potent anti-platelet effects and may have potential for the prevention of platelet-derived vascular diseases.
\end{abstract}

Key words: Cyclic nucleotide, Intracellular $\mathrm{Ca}^{2+}$, Scopoletin, Thromboxane $\mathrm{A}_{2}$

This is an Open Access article distributed under the terms of the Creative Commons Attribution Non-Commercial License (http://creativecommons.org/licenses/by-nc/4.0) which permits unrestricted non-commercial use, distribution, and reproduction in any medium, provided the original work is properly cited.

Copyright @ 2019 The Korean Society for Clinical Laboratory Science. All rights reserved.
Corresponding author: Dong-Ha Lee Department of Biomedical Laboratory Science, Molecular Diagnostics Research Institute, Namseoul University, 91 Daehak-ro, Seonghwan-eup, Seobuk-gu, Cheonan 31020 , Korea

Tel: 82-41-580-2148

Fax: 82-41-580-2932

E-mail:dhlee@nsu.ac.kr

ORCID: https://orcid.org/0000-0002-7042-391X

Received: January 17, 2019

Revised: January 31, 2019

Accepted: February 7, 2019

\section{INTRODUCTION}

Platelet aggregation is essential for the formation of a hemostatic plug when normal blood vessels are injured. However, the interactions between platelets and collagen can also cause circulatory disorder such as thrombosis, atherosclerosis, and myocardial infarction [1]. Collagen supports platelet adhesion to the sub-endothelium and induces subsequently aggregation, secretion, and procoagulant activity. Therefore, inhibition of the plateletcollagen interaction might be a promising approach to the prevention of thrombosis. An important role in collagen- 
induced mechanisms of platelet aggregation is mediated by the formation of thromboxane $\mathrm{A}_{2}\left(\mathrm{TXA}_{2}\right)$ [2], which contributes to an increase in intracellular $\mathrm{Ca}^{2+}$ mobilization $\left(\left[\mathrm{Ca}^{2+}\right]_{\mathrm{i}}\right)$ in collagen-activated platelets. An increase in $\left[\mathrm{Ca}^{2+}\right]_{\mathrm{i}}$ activates both the $\mathrm{Ca}^{2+} /$ calmodulin dependent phosphorylation of myosin light chain (MLC) and the diacylglycerol-dependent phosphorylation of cytosolic pleckstrin to induce platelet aggregation [3, 4]. In addition, diacylglycerol can also be hydrolyzed by diacylglycerol and monoacylglycerol lipase to produce arachidonic acid, a precursor of $\mathrm{TXA}_{2}$, which is a potent platelet aggregation agent generated from arachidonic acid [3-5]. Autocrine agonists, such as adenosine diphosphate (ADP) and $\mathrm{TXA}_{2}$, have been reported to be involved in platelet secretion and aggregation induced by low concentrations of collagen [6].

Verapamil and theophylline have an antiplatelet function by elevating the level of cyclic adenosine monophosphate (cAMP) that decrease the $\left[\mathrm{Ca}^{2+}\right]_{\mathrm{i}}$, an essential factor for platelet aggregation. Vasodilators (such as molsidomine and nitroprusside) and cyclic guanosine monophosphate (cGMP) phosphodiesterase (PDE) inhibitors [such as zaprinast and erythro-9-(2-hydroxy-3-nonyl) adenine] elevate cGMP levels in platelets [5]. The antiplatelet effects of cAMP and cGMP are mediated by cAMP and cGMP-dependent protein kinases (A-kinase and G-kinase, respectively) that phosphorylate the substrate protein vasodilator-stimulated phosphoprotein (VASP) $[7,8]$. VASP is an actin-binding protein and plays an important role in negatively regulating secretion and adhesion [8], and phosphorylation of VASP is known to be associated with inhibition of VASP affinity for contractile protein filamentous actin as well as $\alpha \mathrm{IIb} / \beta_{3}$ [9] .

Scopoletin, which is found commonly in the root of plants in the genus Scopolia or Artemisia, is known to have anti-malaria and anti-coagulation effects [10, 11]. However, little is known regarding the role of scopoletin in platelet aggregation, and the mechanism of scopoletin on collagen-induced human platelet aggregation. In order to clarify the mode of antithrombotic action of scopoletin, we investigated the effect of scopoletin on various parameters associated with collagen-induced platelet aggregation.

\section{MATERIALS AND METHODS}

\section{Materials}

Scopoletin was obtained from Avention Corporation (Seoul, Korea) (Figure 1). Collagen was obtained from Chrono-Log Corporation (Havertown, PA, USA). LDH Cytotoxicity assay kit, and $\mathrm{TXB}_{2}$, ATP, CAMP and cGMP enzymeimmunoassay (EIA) kits were bought from Cayman Chemical (AnnArbor, MI, USA). Fura 2-acetoxymethyl ester (2-AM) and fibrinogen Alexa Fluor 488 conjugate were obtained from Invitrogen (Eugene, OR, USA).

\section{Preparation of human washed platelets}

Human platelet-rich plasma (PRP) was obtained from Korean Red Cross Blood Center (Suwon, Korea). Washed platelets $\left(10^{8}\right.$ platelets $\left./ \mathrm{mL}\right)$ were prepared according to previously published methods [12]. PRP was centrifuged at 1,300 $\mathrm{G}$ for 10 minutes to obtain platelet pellets. This was washed twice with washing buffer $(138 \mathrm{mM} \mathrm{NaCl}, 2.7$ $\mathrm{mM} \mathrm{KCl}, 12 \mathrm{mM} \mathrm{NaHCO}, 0.36 \mathrm{mM} \mathrm{NaH} \mathrm{PO}_{4}, 5.5 \mathrm{mM}$ glucose, and $1 \mathrm{mM}$ EDTA, pH 6.9). The washed platelets were resuspended in suspension buffer $(138 \mathrm{mM} \mathrm{NaCl}, 5.5$ mM glucose, $2.7 \mathrm{mM} \mathrm{KCl}, 12 \mathrm{mM} \mathrm{NaHCO} 3,0.36 \mathrm{mM}$ $\mathrm{NaH}_{2} \mathrm{PO}_{4}, 0.49 \mathrm{mM} \mathrm{MgCl}_{2}$, and $0.25 \%$ gelatin, $\mathrm{pH} 7.4$ ) to a final concentration of $10^{8}$ platelets $/ \mathrm{mL}$. All of the procedures were carried out at $25^{\circ} \mathrm{C}$ to avoid platelet aggregation at low temperature. The experimental use was approved by the Institutional Review Board of the Namseoul University (1041479-HR-201803-003).

\section{Measurement of cytotoxicity}

Cytotoxicity was determined through the leakage of

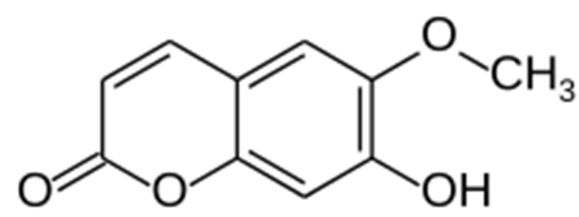

Figure 1. The structure of scopoletin. 
lactate dehydrogenase (LDH) from cytosol. Human washed platelets $\left(10^{8}\right.$ platelets $\left./ \mathrm{mL}\right)$ were incubated for 2 hours at room temperature with various concentrations of scopoletin and then centrifuged at room temperature for 2 minutes at 12,000 G. The supernatant was measured by LDH cytotoxicity assay kit (Cayman Chemical) at an optical density of $490 \mathrm{~nm}$. The cytotoxicity is expressed as the cell viability through the percentage of the total enzyme activity in platelets completely lysed with $0.1 \%$ Triton X-100.

\section{Measurement of platelet aggregation and $\mathrm{TXB}_{2}$}

The washed platelets $\left(10^{8}\right.$ platelets $\left./ \mathrm{mL}\right)$ were preincubated for 3 minutes at $37^{\circ} \mathrm{C}$ with substances, and external $2 \mathrm{mM} \mathrm{CaCl}_{2}$ was added. After that, the washed platelets stimulated with collagen $(2.5 \mu \mathrm{g} / \mathrm{mL})$ for 5 minutes. The aggregation was monitored using an aggregometer (Chrono-Log Co., Havertown, PA, USA) at 1,000 rpm. Each aggregation rate was evaluated as increase in light transmission. The reactions were stopped by the addition of ice-cold EDTA $(5 \mathrm{mM})$ and indomethacin (0.2 mM). The amount of $\mathrm{TXB}_{2}$, a stable metabolite of $\mathrm{TXA}_{2}$, was determined using a $\mathrm{TXB}_{2}$ EIA kit (Cyaman Chemical).

\section{Measurement of cytosolic Free $\mathrm{Ca}^{2+}\left(\left[\mathrm{Ca}^{2+}\right]_{i}\right)$.}

PRP was incubated with $5 \mu \mathrm{M}$ Fura 2-AM for 60 minutes at $37^{\circ} \mathrm{C}$. Because Fura $2-\mathrm{AM}$ is light sensitive, the tube containing the PRP was covered with aluminum foil. The Fura 2-loaded washed platelets were prepared using the procedure described above and $10^{8}$ platelets $/ \mathrm{mL}$ were preincubated for 3 minutes at $37^{\circ} \mathrm{C}$ with or without scopoletin in the presence of $2 \mathrm{mM} \mathrm{CaCl}$ and then stimulated with collagen $(2.5 \mu \mathrm{g} / \mathrm{mL})$ for 5 minutes. The fluorescence of Fura 2 was measured with a spectrofluorometer (SFM 25, BioTeck Instrument, Italy), and the $\left[\mathrm{Ca}^{2+}\right]_{\mathrm{i}}$ values were calculated using the method of a research [13].

\section{Measurement of cyclic nucleotides (cAMP and cGMP)}

The washed platelets $\left(10^{8}\right.$ platelets $\left./ \mathrm{mL}\right)$ were prein- cubated for 3 minutes at $37^{\circ} \mathrm{C}$ with or without various concentrations of scopoletin in the presence of $2 \mathrm{mM}$ $\mathrm{CaCl}_{2}$ and then stimulated with collagen $(2.5 \mu \mathrm{g} / \mathrm{mL})$ for 5 minutes for platelet aggregation. The aggregation was terminated by the addition of $1 \mathrm{M} \mathrm{HCl}$. cAMP and cGMP were measured by using Synergy HT Multi-Model Microplate Reader (BioTek Instruments, Winooski, VT, USA).

\section{Measurement of fibrinogen binding to $\alpha \mathrm{llb} / \beta_{3}$}

The platelet aggregation assay was conducted at $37^{\circ} \mathrm{C}$ for $5 \mathrm{~min}$, with Alexa Flour 488-human fibrinogen (30 $\mu \mathrm{g} / \mathrm{mL}$ ) binding platelets. To terminate the reaction, $0.5 \%$ paraformaldehyde in phosphate-buffered saline (PBS, pH 7.4) was added. The mentioned procedures were conducted in darkness. The fibrinogen binding assay was performed using flow cytometry (BD Biosciences, San Jose, CA, USA), and analyzed with the CellQuest software (BD Biosciences).

\section{Measurement of ATP release}

The washed platelets $\left(10^{8}\right.$ platelets $\left./ \mathrm{mL}\right)$ were preincubated for 3 minutes at $37^{\circ} \mathrm{C}$ with or without various concentrations of scopoletin in the presence of 2 $\mathrm{mM} \mathrm{CaCl} 2$ and then stimulated with collagen $(2.5 \mu \mathrm{g} / \mathrm{mL})$ for 5 minutes. The reaction was terminated and centrifuged with $1,000 \mathrm{G}$ at $4^{\circ} \mathrm{C}$ for 10 minutes, and the supernatant was used for ATP release assay. ATP release was measured with an ATP assay kit in a luminometer (BioTek Instruments).

\section{Statistical analysis}

The results are expressed as means \pm SD. Statistical analysis was performed with a two tailed-unpaired Student's t-test or ANOVA, as appropriate. If there were significant differences between the group means according to ANOVA, each group was compared by Scheffe's method. 


\section{RESULTS}

\section{Effects of scopoletin on platelet aggregation and cytotoxicity}

As shown in Figure 2A, the platelet aggregation induced by collagen was $98.0 \pm 2.0 \%$, but scopoletin $(50,100,300$ and $500 \mu \mathrm{M}$ ) significantly reduced platelet aggregation by $89.0 \pm 5.3,64.3 \pm 7.4,47.3 \pm 7.6$ and $16.3 \pm 3.6 \%$, respectively. In addition, the cytotoxicity of scopoletin to human platelets was confirmed to have no significant effects (Figure. 2B). This means that it is valuable as a platelet aggregation inhibitor.

\section{Effects of scopoletin on $\mathrm{TXB}_{2}$ and $\left[\mathrm{Ca}^{2+}\right]_{\mathrm{i}}$}

The amount of $\mathrm{TXB}_{2}$ in intact platelets was $2.4 \pm 1.1$ $\mathrm{ng} / 10^{8}$ platelets, and this was increased to $185.9 \pm 13.4$ $\mu \mathrm{g} / 10^{8}$ platelets when platelets were stimulated with collagen $(2.5 \mu \mathrm{g} / \mathrm{mL})$. However, scopoletin (100, 300 and $500 \mu \mathrm{M})$ significantly reduced the levels of $\mathrm{TXB}_{2}$ in dose-dependent (Figure 3A). As shown in Figure 3B, scopoletin $(50,100,300$ and $500 \mu \mathrm{M})$ strongly inhibited $\left[\mathrm{Ca}^{2+}\right]_{\mathrm{i}}$ increased by collagen.

\section{Effects of scopoletin on cyclic nucleotides}

Both cAMP and cGMP are known to be negative regulators of platelet aggregation due to a decrease in $\left[\mathrm{Ca}^{2+}\right]_{\mathrm{i}}$ levels [14]. Therefore, we investigated whether scopoletin affects cellular levels of cAMP or cGMP. As shown in Figure 4A, scopoletin strongly increased cAMP levels from $3.9 \pm 0.4 \mathrm{pmoL} / 10^{8}$ platelets to $10.2 \pm 0.5$ pmoL/ $10^{8}$ platelets. On the other hand, although cGMP was increased by scopoletin from $6.5 \pm 0.5 \mathrm{pmoL} / 10^{8}$

B

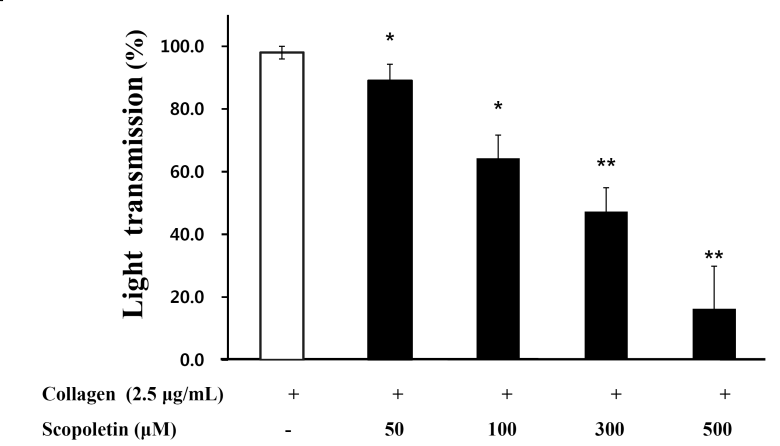

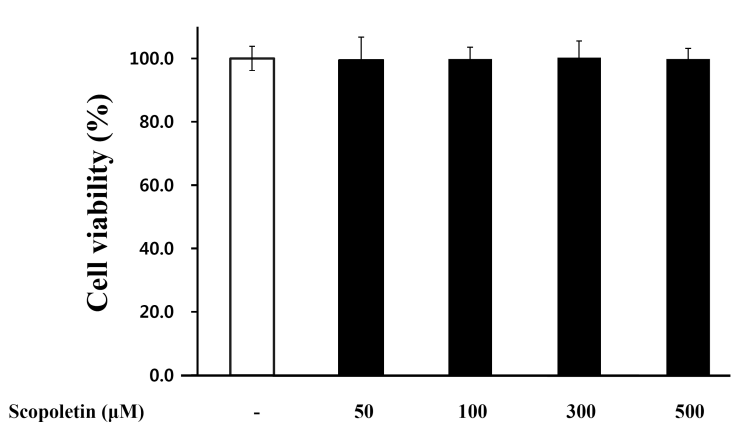

Figure 2. Effects of scopoletin on platelet aggregation. (A) Effects of scopoletin on platelet aggregation stimulated by collagen. (B) Effects of scopoletin on cytotoxicity. Data are expressed as mean $\pm \mathrm{SD}(\mathrm{N}=4)$. '*' or '**' mean $P<0.05$ or $P<0.001$ compared with the collagen-stimulated platelets.

A

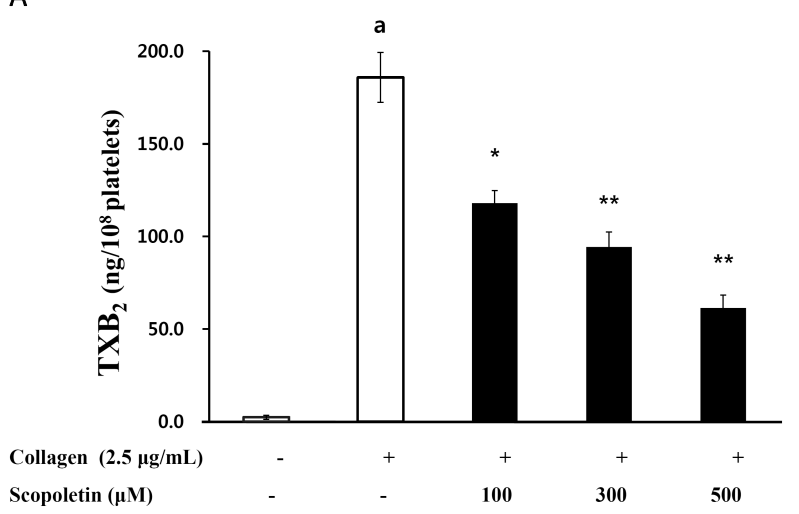

B

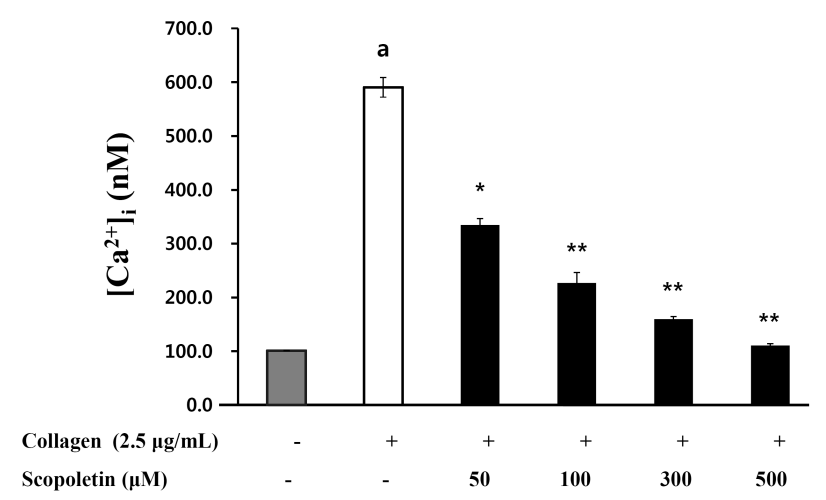

Figure 3. Effects of scopoletin on $\mathrm{TXB}_{2}$ production and $\left[\mathrm{Ca}^{2+}\right]_{i}(\mathrm{~A})$ Effects of scopoletin on $\mathrm{TXA}_{2}$ production stimulated by collagen. (B) Effects of scopoletin on $\left[\mathrm{Ca}^{2+}\right]_{i}$ stimulated by collagen. Data are expressed as mean $\pm \mathrm{SD}(\mathrm{N}=4)$. 'a' means $P<0.05$ compared with no-stimulated platelets, '*' or ' $* *$ ' means $P<0.05$ or $P<0.001$ compared with the collagen-stimulated platelets. 
A

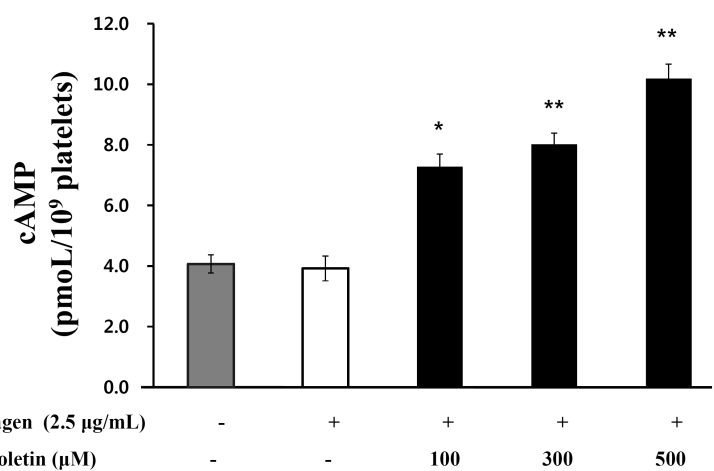

B

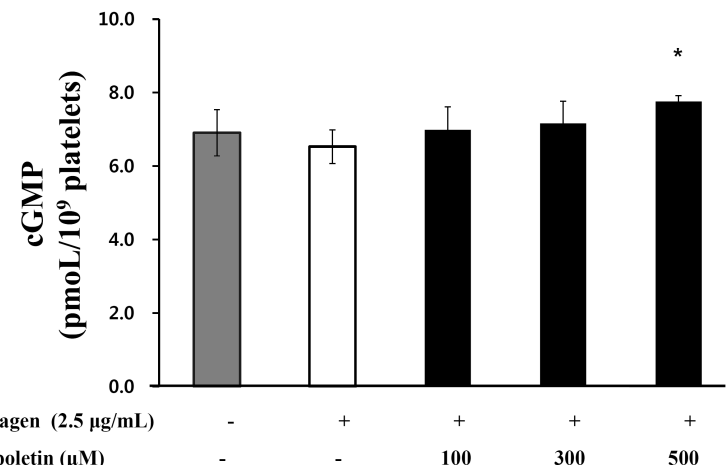

Figure 4. Effects of scopoletin on cyclic nucleotides production. (A) Effects of scopoletin on cAMP production stimulated by collagen. (B) Effects of scopoletin on CGMP production stimulated by collagen. Data are expressed as mean $\pm \mathrm{SD}(\mathrm{N}=4)$. '* or ${ }^{* \prime}$ ' mean $P<0.05$ or $P<0.001$ compared with the collagen-stimulated platelets.

A
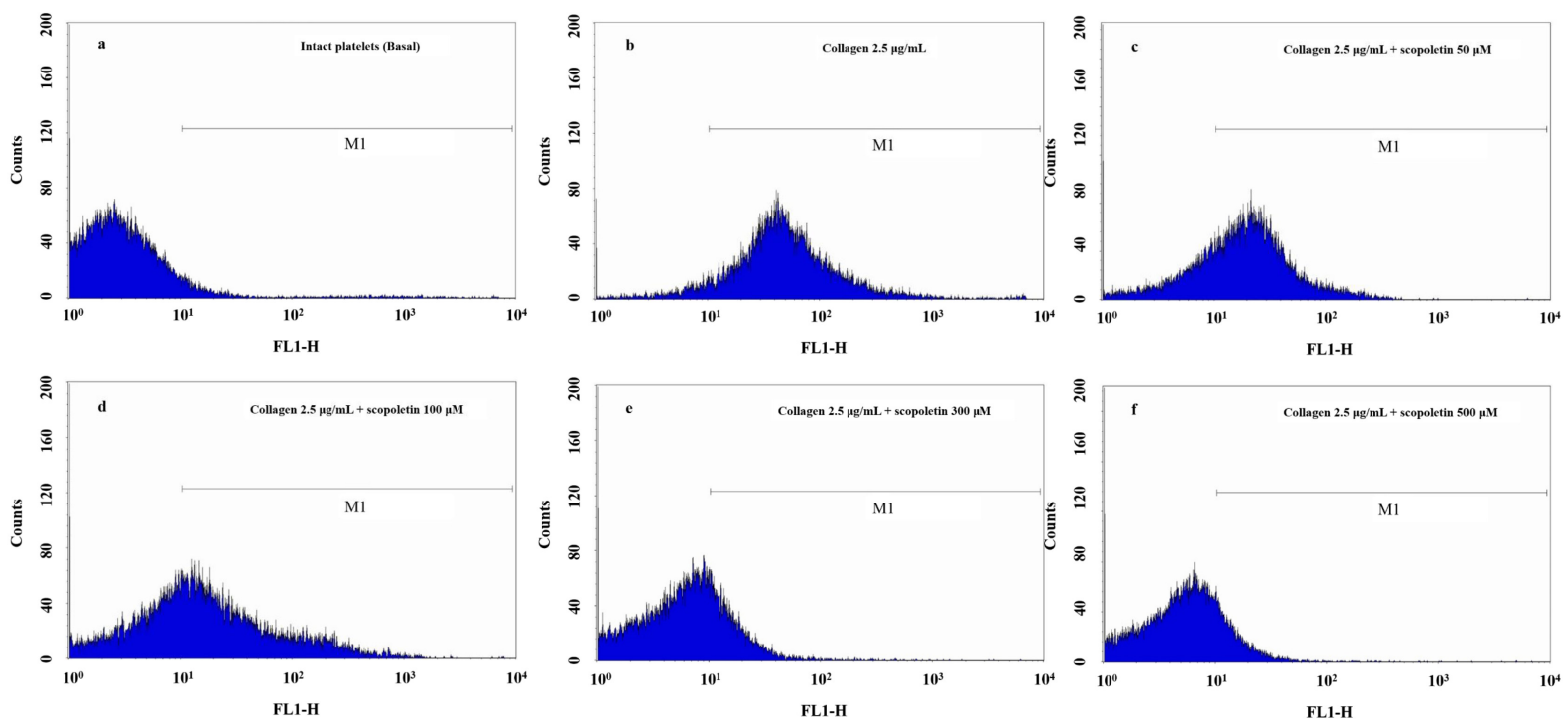

B

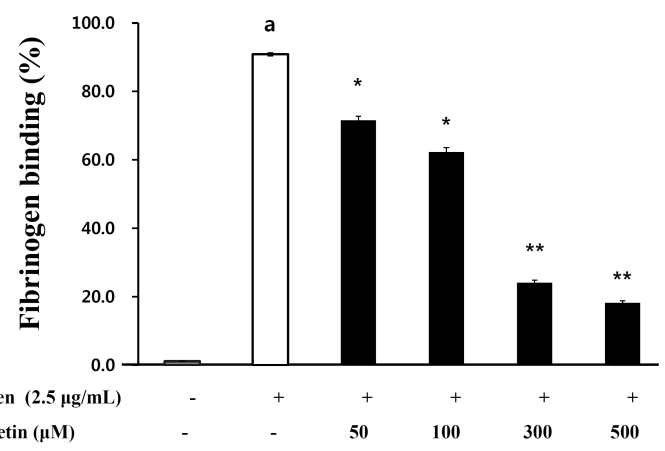

platelets to $7.8 \pm 0.2 \mathrm{pmoL} / 10^{8}$ platelets, it was not as Figure 5. Effects of scopoletin on fibrinogen binding. (A) Effects of scopoletin on fibrinogen binding. stimulated by collagen. a, Intact platelets; b, Collagen $(2.5 \mu \mathrm{g} / \mathrm{mL}) ; \mathrm{c}$, Collagen $(2.5$ $\mu \mathrm{g} / \mathrm{mL})+$ scopoletin $(50 \mu \mathrm{M})$; d, Collagen $(2.5 \mu \mathrm{g} / \mathrm{mL})+$ scopoletin $(100 \mu \mathrm{M}) ; \mathrm{e}$, Collagen $(2.5 \mu \mathrm{g} / \mathrm{mL})+\operatorname{scopoletin}(300 \mu \mathrm{M}) ; \mathrm{f}$, Collagen $(2.5 \mu \mathrm{g} / \mathrm{mL})+$ scopoletin $(500 \mu \mathrm{M})$. (B) Effects of scopoletin on collagen-stimulated fibrinogen binding (\%). These data were expressed as the mean \pm SEM $(N=4)$, 'a' means $P<$ 0.05 compared with no-stimulated platelets, '*' or '**' means $P<0.05$ or $P<0.001$ compared with the collagen-stimulated platelets.

strong as cAMP (Figure 4B). These results indicate that in collagen-stimulated platelets. scopoletin upregulates the production of cAMP and cGMP 


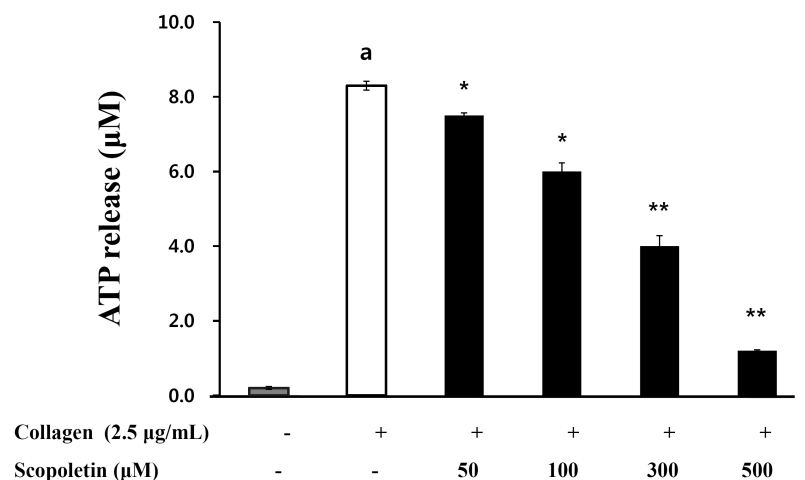

Figure 6. Effects of scopoletin on ATP release. Data are expressed as mean $\pm \mathrm{SD} \quad(\mathrm{N}=4)$. 'a' means $P<0.05$ compared with no-stimulated platelets, '*' or '**' means $P<0.05$ or $P<0.001$ compared with the collagen-stimulated platelets.

\section{Effects of scopoletin on fibrinogen binding to $\alpha \mathrm{llb} / \beta_{3}$}

Increased nucleotides are known to inhibit fibrinogen binding to $\alpha I \mathrm{Ib} / \beta_{3}$ complex, which are concerned with inhibition of platelet activation [15, 16]. Therefore, we examined whether scopoletin inhibits fibrinogen binding to $\alpha \mathrm{IIb} / \beta_{3}$. As shown in Figure $5 \mathrm{~A}$ and $5 \mathrm{~B}$, collagen increased potently fibrinogen binding to $\alpha \mathrm{IIb} / \beta_{3}$ compared with intact cell from $1.2 \pm 0.1 \%$ to $90.8 \pm 0.5 \%$. However, scopoletin inhibited dose-dependently collagen-induced fibrinogen binding to $\alpha \mathrm{IIb} / \beta_{3}$ from $90.8 \pm 0.5 \%$ to $18.2 \pm 0.6 \%$.

\section{Effects of scopoletin on ATP}

As shown in Figure 6, ATP level in supernatant from the collagen-induced platelets was $8.3 \pm 0.1 \mu \mathrm{M}$, which is 41.5 fold as compared with that $(0.2 \pm 0.1 \mu \mathrm{M})$ in intact cell. However, scopoletin (50, 100, 300 and $500 \mu \mathrm{M})$ inhibited dose-dependently collagen-elevated ATP release from $8.3 \pm 0.1 \mu \mathrm{M}$ to $1.2 \pm 0.1 \mu \mathrm{M}$, and scopoletin $(500 \mu \mathrm{M})$ inhibited potently ATP release to $85.5 \%$ as compared with collagen-induced ATP.

\section{DISCUSSION}

During platelets activation, PLC- $\gamma_{2}$ hydrolyzes phosphatidylinositol 4,5-bisphosphate $\left(\mathrm{PIP}_{2}\right)$ with $\mathrm{IP}_{3}$ and diacylglycerol (DAG). In addition, $\mathrm{IP}_{3}$ causes $\mathrm{Ca}^{2+}$ mobilization from the endoplasmic reticulum, and DAG activates DAG-dependent protein kinase C [17]. Increased $\left[\mathrm{Ca}^{2+}\right]_{\mathrm{i}}$ results to phosphorylation of myosin light chain (20-kDa) and cytosolic protein (40- or 47-kDa) through $\mathrm{Ca}^{2+} /$ calmodulin-dependent phosphorylation, which lead to induce platelet aggregation [3]. Thromboxane $\mathrm{A}_{2}\left(\mathrm{TXA}_{2}\right)$ is a potent vasoconstrictor that stimulates platelet aggregation and subsequent platelet activation. $\mathrm{TXA}_{2}$ is finally produced from arachidonic acid through $\mathrm{PGH}_{2}$ by the action of enzymes such as cyclooxygenase (COX) and thromboxane A synthase (TXAS) [18]. It is known that the reduction of $\mathrm{TXA}_{2}$ is essential for the antithrombotic process by inhibiting platelets activation. In this study, scopoletin suppressed $\mathrm{TXA}_{2}$ production and $\left[\mathrm{Ca}^{2+}\right]_{\mathrm{i}}$ in human platelet dose-dependently, as the result, inhibit platelet aggregation.

Cyclic nucleotides are known to reduce $\mathrm{Ca}^{2+}$ influx and inhibit platelet aggregation through cAMP-and cGMPdependent protein kinases [19]. In this study, scopoletin increased cAMP- and cGMP production in platelets. These results indicate that the increase of cyclic nucleotides by scopoletin can play a central role in platelet aggregation. The cAMP and cGMP are dependent on the activation of adenylyl cyclase/guanyl cyclase or cyclic nucleotide phosphodiesterases (PDEs) [20]. Inhibition of PDE activity increases the level of cyclic nucleotides in platelet aggregation [21]. Thus, PDE inhibitors may have therapeutic potential for thrombosis. Indeed, PDE inhibitors such as triflusal, cilostazol and dipyridamole have been used clinically as antiplatelet drugs to increase the production of cyclic nucleotides [5, 22]. Therefore, scopoletin might affect the activity of cyclic nucleoside phosphodiesterase, and further studies are required to reveal this. In any case, scopoletin increased the production of the cytoplasmic nucleosides such as cAMP and cGMP, especially cAMP increased potently.

Increased cAMP production in platelets has been reported to inhibit platelet activation via VASP $\operatorname{ser}^{157}$ phosphorylation [23, 24]. VASP is a major substrate for cAMP-dependent PKA, and stimulation of VASP inhibits platelet activation by modulating the secretory and 
adhesive properties of platelets [25]. Moreover, VASP phosphorylation also inhibits the activation of integrin $\alpha \mathrm{IIb} / \beta_{3}$, which consequently inhibits platelet aggregation. In our study, scopoletin significantly suppressed fibrinogen binding to $\alpha I b \beta_{3}$ induced by collagen, which may be due to the elevation of cAMP production. These results indicate that scopoletin have therapeutic potential against platelet-related disorders, which might be related to cyclic nucleotides-downstream pathway. In addition, the increase of ATP release from dense body in platelets is known to be involved in amplification of platelet aggregation [26, 27], Because scopoletin inhibited ATP release dose-dependently, it is thought to have helped inhibit aggregation amplification. These results suggest that scopoletin, one of the phytochemical compounds, may have an inhibitory effect on collagen-induced human platelet aggregation by regulating aggregation-inducing molecules $\left(\mathrm{TXA}_{2}\right.$ and $\mathrm{Ca}^{2+}$ ) and aggregation-inhibiting molecules (cAMP and cGMP).

In conclusion, we have presented many evidences that scopoletin is an effective antiplatelet agent. This study suggests that scopoletin has a preventive effect on platelet derived vascular thrombosis.

\section{요 약}

혈소판 응집은 혈관 손상의 경우 지혈 플러그 형성에 필수적 이다. 그러나, 과도한 혈소판 응집은 혈전증, 죽상 동맥 경화증 및 심근 경색과 같은 순환기 장애를 일으킬 수도 있다. Scopoletin은 Scopolia 또는 Artemisia 속 식물의 뿌리에서 발 견되는 성분으로, 항응고 및 항말라리아 작용을 가지는 것으로 알려져 있다. 본 연구는 collagen에 의해 유발된 혈소판 응집에 scopoletin이 미치는 영향을 조사하였다. Scopoletin은 활성화 된 혈소판에서 생성되는 응집 유도 분자인 thromboxane $\mathrm{A}_{2}$ $\left(\mathrm{TXA}_{2}\right)$ 및 세포 내 $\mathrm{Ca}^{2+}$ 동원 $\left(\left[\mathrm{Ca}^{2+}\right]_{\mathrm{i}}\right)$ 의 하향 조절을 통해 항 혈 소판 효과를 나타내었다. 한편, scopoletin은 세포 내 $\mathrm{Ca}^{2+}$-길 항제인 것으로 알려져 있는 cyclic adenosine monophosphate (cAMP)와 cyclic guanosine monophosphate (cGMP) 수치를 증가시켰다. 특히, scopoletin은 cGMP보다 cAMP 수준을 강 력하게 증가함으로써 콜라겐에 의해 유발된 사람 혈소판 응집 에서의 $\alpha \mathrm{IIb} / \beta_{3}$ 에 대한 피브리노겐 결합을 억제하였다. 또한, scopoletin은 용량 의존적으로 collagen에 의해 증가된 adenosine trisphosphate (ATP)의 방출을 억제하였다. 이 결 과는 혈소판 내 과립 분비를 통한 응집 증폭작용이 scopoletin 에 의해 억제되었음을 의미한다. 따라서, 본 연구는 scopoletin 이 강력한 항혈소판 효과를 가지며 혈소판-유래의 혈관 질환을 예방할 가능성이 크다는 것을 입증하였다.

\section{Acknowledgements: None \\ Conflict of interest: None}

Author's information (Position): Kwon $\mathrm{HW}^{1}$, Professor; Shin $\mathrm{JH}^{1}$, Researcher; Park $\mathrm{CE}^{2}$, Professor; Lee $\mathrm{DH}^{2}$, Professor.

\section{REFERENCES}

1. Schwartz SM, Heinmark RL, Majesky MW. Developmental mechanisms underlying pathology of arteries. Physiol Rev. 1990;70:1177-1209. https://doi.org/10.1152/physrev.1990.70. 4.1177.

2. Cattaneo M, Tenconi PM, Lecchi A, Mannucci PM. In vitro effects of picotamide on human platelet aggregation, the release reaction and thromboxane B2 production. Thromb Res. 1991;62:717-724.

3. Nishikawa M, Tanaka T, Hidaka H. Ca2+-calmodulin-dependent phosphorylation and platelet secretion. Nature. 1980; 287:863-865.

4. Kaibuchi K, Sano K, Hoshijima M, Takai Y, Nishizuka Y. Phosphatidylinositol turnover in platelet activation; calcium mobilization and protein phosphorylation. Cell Calcium. 1982;3:323-335.

5. Menshikov MYu, Ivanova K, Schaefer M, Drummer C, Gerzer R. Influence of the cGMP analog 8-PCPT-cGMP on agonist-induced increases in cytosolic ionized $\mathrm{Ca} 2+$ and on aggregation of human platelets. Eur J Pharmacol. 1993;245:281-284.

6. Atkinson BT, Stafford MJ, Pears CJ, Watson SP. Signalling events underlying platelet aggregation induced by the glycoprotein VI agonist convulxin. Eur J Biochem. 2001;268:5242-5248.

7. Kawada T, Toyosato A, Islam MO, Yoshida Y, Imai S. cGMPkinase mediates CGMP- and cAMP-induced $\mathrm{Ca}^{2+}$ desensitization of skinned rat artery. Eur J Pharmacol. 1997;323:75-82.

8. Calderwood DA, Shattil SJ, Ginsberg MH. Integrins and actin filaments: reciprocal regulation of cell adhesion and signaling. J Biol Chem. 2000;275:22607-22610. https://doi.org/10.1074/ jbc.R900037199.

9. Smolenski A, Burkhardt AM, Eigenthaler M, Butt E, Gambaryan S, Lohmann SM, et al. Functional analysis of cGMP-dependent protein kinases I and II as mediators of NO/cGMP effects. Naunyn Schmiedebergs Arch Pharmacol. 1998;358:134-139.

10. Towler MJ, Weathers PJ. Variations in key artemisinic and other metabolites throughout plant development in Artemisia annua L. for potential therapeutic use. Ind Crops Prod. 2015; 
67:185-191. https://doi.org/10.1016/j.indcrop.2015.01.007.

11. Obasi SC, Njoku OU, Obidoa O. Effects of single oral doses of scopoletin and aflatoxin B1 on the clotting time, serum cholesterol and phospholipid levels of chicks. Indian J Physiol Pharmacol. 1994;38:89-94.

12. Kwon HW, Lee DH. The inhibitory effects of cordycepin on phosphoproteins including PI3K, Akt, and p38. Korean J Clin Lab Sci. 2017;49:99-107. https://doi.org/10.15324/kjcls.2017. 49.2.99.

13. Schaeffer J, Blaustein MP. Platelet free calcium concentrations measured with fura-2 are influenced by the transmembrane sodium gradient. Cell Calcium. 1989;10:101-113.

14. Kawada N, Uoya M, Seki S, Kuroki T, Kobayashi K. Regulation by cAMP of STAT1 activation in hepatic stellate cells. Biochem Biophys Res Commun. 1997;233:464-469. https://doi.org/ 10.1006/bbrc.1997.6481.

15. Horstrup K, Jablonka B, Hönig-Liedl P, Just M, Kochsiek K, Walter U. Phosphorylation of focal adhesion vasodilatorstimulated phosphoprotein at Ser157 in intact human platelets correlates with fibrinogen receptor inhibition. Eur J Biochem. 1994;225:21-27.

16. Barragan P, Bouvier JL, Roquebert PO, Macaluso G, Commeau $\mathrm{P}$, Comet B, et al. Resistance to thienopyridines: clinical detection of coronary stent thrombosis by monitoring of vasodilator-stimulated phosphoprotein phosphorylation. Catheter Cardiovasc Interv. 2003;59:295-302. https://doi.org/10.1002/ ccd.10497.

17. Berridge MJ, Irvine RF. Inositol phosphates and cell signalling. Nature. 1989;341:197-205. https://doi.org/10.1038/341197a0.

18. Okwu AK, Ullian ME, Halushka PV. Homologous desensitization of human platelet thromboxane A2/prostaglandin $\mathrm{H} 2$ receptors. J Pharmacol Exp Ther. 1992;262:238-245.

19. Kuo JF, Andersson RG, Wise BC, Mackerlova L, Salomonsson I, Brackett NL, et al. Calcium-dependent protein kinase: widespread occurrence in various tissues and phyla of the animal kingdom and comparison of effects of phospholipid, calm- odulin, and trifluoperazine. Proc Natl Acad Sci USA. 1980;77: 7039-7043.

20. Gao J, Tao J, Liang W, Zhao M, Du X, Cui S, et al. Identification and characterization of phosphodiesterases that specifically degrade 3'3'-cyclic GMP-AMP. Cell Res. 2015;25:539-550. https://doi.org/10.1038/cr.2015.40.

21. Haslam RJ, Dickinson NT, Jang EK. Cyclic nucleotides and phosphodiesterases in platelets. Thromb Haemost. 1999; 82:412-423.

22. Napeñas J, Oost FC, DeGroot A, Loven B, Hong CH, Brennan MT, et al. Review of postoperative bleeding risk in dental patients on antiplatelet therapy. Oral Surg Oral Med Oral Pathol Oral Radiol. 2013;115:491-499. https://doi.org/10.1016/j. oooo.2012.11.001.

23. Wangorsch G, Butt E, Mark R, Hubertus K, Geiger J, Dandekar $\mathrm{T}$, et al. Time-resolved in silico modeling of finetuned cAMP signaling in platelets: feedback loops, titrated phosphorylations and pharmacological modulation, BMC Syst Biol. 2011;5:178. https://doi.org/10.1186/1752-0509-5-178.

24. Coles B, Bloodsworth A, Eiserich JP, Coffey MJ, McLoughlin RM, Giddings JC, et al. Nitrolinoleate inhibits platelet activation by attenuating calcium mobilization and inducing phosphorylation of vasodilator-stimulated phosphoprotein through elevation of cAMP. J Biol Chem. 2002;277:5832-5840. https://doi.org/10.1074/jbc.M105209200.

25. Wentworth JK, Pula G, Poole AW. Vasodilator-stimulated phosphoprotein (VASP) is phosphorylated on Ser157 by protein kinase C-dependent and -independent mechanisms in thrombin-stimulated human platelets. Biochemical J. 2006;393: 555-564. https://doi.org/10.1042/BJ20050796.

26. Holmsen H, Day HJ. The selectivity of the thrombininduced platelet release reaction: subcellular localization of released and retained constituents. J Lab Clin Med. 1970;75:840-855.

27. Mustard JF, Packham MA. Factors influencing platelet function: adhesion, release, and aggregation. Pharmacol Rev. 1970;22: 97-187. 